\title{
MODELLING MICRO ENTERPRISES' BEHAVIORAL INTENTION TO ADOPT INTEGRATED ISLAMIC CROWDFUNDING-MICRO ENTERPRISE (IICME) MODEL AS A SOURCE OF FINANCING IN EAST JAVA, INDONESIA
}

\author{
Mohamed Asmy Bin Mohd Thas Thaker*1 (D) \\ Hassanudin Bin Mohd Thas Thaker ${ }^{2}$ D
}

${ }^{1}$ Associate Professor, Department of Economics, International Islamic University Malaysia, Malaysia

${ }^{2}$ Associate Professor, Department of Economics and Finance, Sunway University, Malaysia

\begin{abstract}
The present study has proposed Integrated Islamic Crowdfunding-Micro Enterprise (IIC$M E)$ model to assist micro enterprises in meeting their need to access external financial services in East Java, Indonesia. Upon the proposed model, this study examines the behavioural intention of micro enterprises to use IICME model. The primary data are collected from the survey administered to micro enterprises in the East Java (Pasuruan, Malang, Kediri, Ponorogo, and Gresik) and the analysis is conducted using Partial Least Squares (SmartPLS). Furthermore, the model has been validated its acceptance in the field by adopting the extended Technology Acceptance Model (TAM). This study has revealed that the perceived usefulness, perceived easy to use and perceived benefit are found to have a positive impact on the intention of micro enterprises to use IICME model, which later assist them to access to financial services in Indonesia. Furthermore, perceived easy to use has a positive relationship and direct effect with perceived usefulness of micro enterprises to use the IICME model. The findings of this study can be used to develop a specific framework in which to examine other components of using the IICME model's behavior and to plan appropriate intervention strategies to increase financial accessibility by micro enterprises.
\end{abstract}

Keywords: Islamic Crowdfunding, Micro Enterprises, Financing, Technology Acceptance Model

\begin{abstract}
ABSTRAK
Penelitian ini mengusulkan model Integrated Islamic Crowdfunding-Micro Enterprise (IICME) untuk membantu usaha mikro dalam memenuhi kebutuhan mereka untuk mengakses layanan keuangan eksternal di Jawa Timur, Indonesia. Atas model yang diusulkan, penelitian ini menguji niat perilaku usaha mikro untuk menggunakan model IICME. Data primer dikumpulkan dari survei yang dilakukan pada usaha mikro di Jawa Timur (Pasuruan, Malang, Kediri, Ponorogo, dan Gresik) dan analisis dilakukan menggunakan Partial Least Squares (SmartPLS). Selanjutnya model tersebut telah divalidasi penerimaannya di lapangan dengan mengadopsi Extended Technology Acceptance Model (TAM). Studi ini mengungkapkan bahwa persepsi kegunaan, persepsi mudah digunakan, dan manfaat dirasakan berdampak positif pada niat usaha mikro untuk menggunakan model IICME, yang kemudian membantu mereka mengakses layanan keuangan di Indonesia. Selanjutnya, persepsi kemudahan penggunaan memiliki hubungan positif dan efek langsung dengan persepsi manfaat usaha mikro untuk menggunakan model IICME. Temuan penelitian ini dapat digunakan untuk mengembangkan kerangka kerja khusus untuk menguji komponen lain dalam menggunakan perilaku model IICME dan untuk merencanakan strategi intervensi yang tepat untuk meningkatkan aksesibilitas keuangan oleh usaha mikro.
\end{abstract}

Kata kunci: Crowdfunding Syariah, Usaha Mikro, Pembiayaan, Model Penerimaan Teknologi JEL: G23; M10

East Java Economic Journal, p-ISSN: 2597-8780, DOI: 10.53572/ejavec.v2i2.23, Open access under a Creative Commons Attribution- 4.0 


\section{Introduction}

The role of micro enterprises on the national economy in any country cannot be underestimated. Successful micro enterprises become the primary engines of economic development, income growth, and poverty reduction in many of the developing and emerging economies. A smooth role of micro enterprises remains a concern not only for the policy makers but also to the practitioner as well as other stakeholders. This is one of the reasons behind the existence of various supporting bodies including both government and private agencies that oversee the smooth running of their business operations. A failure of micro enterprises development may have a major impact on socio-economic development especially on reducing poverty at both the local and national levels. It is noted that the contribution of micro enterprises also cover a wide range of areas and sectors with disproportionate number of total establishments in many countries.

Statistics show that MEs represent about more than 70 percent of the total SMEs establishments in the most world economies and contribute more than 80 percent of total employment, including in Indonesia. The statistics from Indonesian Ministry of Cooperatives and SMEs indicated that micro enterprises constitute more than 85 percent of Indonesian's total business establishment, employ about 90 percent of the total workforce and contribute 37 percent to the country's GDP. Majority of micro enterprises in Indonesia are more prevalently in services (including trade) and agriculture sector, with more than $50 \%$ and $40 \%$, respectively. In Indonesia also, more micro and small enterprises than medium enterprises are found in trade and agriculture, while medium enterprises are more involved in manufacturing activities. Indeed, the growth generated through the micro enterprises because of their numbers, and the jobs they have provided in recent years, are the main drivers of reducing poverty and rising incomes.

According to BPS (2014) report, Indonesia has approximately 28 million people live under the poverty which is about 4.8 million poor people live in East Java province. Since the large number of population (15.42 percent of total Indonesia's population) live in East Java, they contributed significantly to the national poverty level. The significant number of poor in the country including East Java relies heavily on informal sector for their livelihood (i.e. micro enterprises activity). They are predominantly microenterprises which are mostly concentrated in agriculture and trading sectors. These real sector activities continue to be central of economic development strategy for the poor and their development has potential in providing income growth and poverty alleviation.

Despite this recognized importance and its contribution towards the economy, a considerable number of empirical studies that investigate the problem of assessing external finance by micro enterprises in Indonesia exist (Tambunan, 2011; Machmud \& Huda, 2011; Razak et al. ,2017; Tambunan, 2009; Burger et al., 2015). Those studies empirically and conceptually have found that (i) inadequate collateral, (ii) insufficient legal status, (iii) high transaction costs, (iv) insufficient information and documentation, (v) no financial track record, (vi) nature and quality of business, (vii) rigidity of the financing procedure and (viii) lack of awareness on financial facility are among the prominent factors that hindered micro enterprises from accessing external finance. Furthermore, most of the financial institutions reluctant not to serve MEs because the latter are perceived as high risks of default, high costs of transactions and perceived low relative profitability.

Financing for micro enterprises in the appropriate forms is important in order to enable these firms to start up, develop and grow, and make contributions to employment, growth and social inclusion. The Indonesian government has responded to particular issue by allocating a huge amount for financial assistance and providing various programmes, however, hitherto the effort is seen as ineffective when the impacts of business activities are found to be insignificant. Such situation occurs when the assistance program is offered through many government or private agencies without appropriate observation. Furthermore, Abdullah (1999) 
claimed that ineffectiveness of government assistance programs is due to: (i) limited number of micro enterprises receives full range of assistance, (ii) inefficient allocation of resources, and (iii) the programs focusing on developing only new enterprises. Therefore, in spite of the government efforts to promote accessing to finance through various measures, micro enterprises are continuously facing the problem of accessing finance.

It can, therefore, be rightly asserted that the micro enterprises' financial accessibility requires a new innovative financing mechanism and source of funding in addition to the government funding. As such, a new mechanism that will allow for a sustainable source of financing is needed in assisting micro enterprises in Indonesia, particularly in East Java. In lieu with this, the present study proposed Integrated Islamic Crowdfunding-Micro Enterprise (IICME) model. Integrated Islamic Crowdfunding-Micro Enterprise (IICME) model is expected to be as a suitable model that can effectively address or minimize the constraint of financial accessibility by micro enterprises in East Java, Indonesia. Later, this study uses of the theory of Technology Acceptance Model (TAM) to justify the behavioral intention of micro enterprises to using the proposed model. To the best knowledge of the researcher, there has been none of the research investigate empirically the optimalisation of Islamic-based crowdfunding as a source of financing for micro enterprises using TAM.

Accordingly, the main objective of this paper is to propose Integrated Islamic Crowdfunding-Micro Enterprise (IICME) model and test the behavioural intention of micro enterprises to use IICME model as source of financing their business. The remaining part of this paper is therefore organised as follows: the second section presents literature review. Section three presents the methodology applied in this study. Section five presents the main results of the study and its discussion. Section six provides the conclusion and policy recommendations.

\section{Literature Review}

\section{Micro Enterprises Financial Challenges}

Throughout the years, there are large numbers of literature investigating micro enterprises' financing constraint worldwide and this problem also exists in Indonesia. The availability of external finance for micro enterprises is a topic of significant research interest to academics and issues of great importance to policy makers around the globe (Berger and Udell, 2006). Shortage of finance has been reported as a particular problem for micro enterprises all over the world and currently one of the most important challenges faced by Indonesian micro enterprises (Tambunan, 2011).

Irjayanti and Azis (2012) attempted to identify the barriers that faced by micro enterprises in Indonesia. Based on findings from survey of micro enterprises and in-depth interviews, they found that the major problem hindered the growth of micro enterprises was the lack of financial accessibility. Micro enterprises that has little access to bank loans, either because of technical constraints, such as not having or insufficient collateral, or non-technical constraints, such as limited access to banking information. In addition, micro enterprises faced difficulties when they tried to apply for credit financing from banks, due to the complex requirement that could not be fulfilled by the micro enterprises.

In another study by Tambunan (2009), he stated that Indonesian micro enterprises face many obstacles, especially in terms of accessing to finance. Micro enterprises face harder competition without any access to bank loans or government financing institution. They must seek for their own financing through loans, informal businesses and face another problem like high rate of return demanded by informal lending institutions.

Machmud \& Huda (2011) examined the financial constraints faced by Indonesian micro enterprises. Based on their findings, about 44 percent of SME respondents relied on internal financial sources, particularly personal savings and retained earnings. The respondents indicated that the two most important reasons to turn down a loan application are: (i) poor 
credit history and (ii) poor business plan.

Razak et al. (2017) empirically examined the main factors that hinder micro enterprises to access financing from mainstream banking in Indonesia's province of East Java. Based on their findings using survey, Micro enterprises were excluded from accessing external finance because of high interest rate, expensive fee, no financial track record, lack of documentation, collateral requirement, lack of knowledge, strict documentation requirement, and insufficient amount of borrowing.

Using qualitative approach, Tambunan (2011) showed that lack of access to formal credit and financial institutions was indeed a key concern of micro enterprises in Indonesia. This constraint is related to the ability of Mea to offer the type of collateral normally required to access bank loans. Furthermore, he also found that although there were various government-sponsored credit schemes for SMEs, the majority of micro enterprises located in rural areas, never receive credit from such schemes. Instead, micro enterprises depended fully on their own savings, money from relatives, and credit from informal lenders for financing their daily business operations.

Burger et al. (2015) conducted structured interviews with micro enterprises across five provinces in Indonesia to investigate the constraints that firms face. According to their findings, it showed that despite the variety of constraints that firms could face in doing business, credit constraints emerged as most important constraint. Many of the micro enterprises that were interviewed by the authors felt that the terms of credit offered to micro enterprises by banks were too expensive, with excessive interest rates and difficult collateral requirements. Indeed, the banks are unwilling to provide credit to small firms because investment in new businesses is inherently risky, small firms often fail and many firms often have no collateral to secure the loan. To offer credit to new businesses without collateral, banks have to charge high interest rates that would make many firms unprofitable.

The challenges facing the Indonesian micro enterprises are apparently shared by micro enterprises in other countries. For example, Stephanou \& Rodriguez (2008) examined the financing challenges of micro enterprises in Colombia. Based on data collection and interviews with the authorities of micro enterprises, lack of access to finance has been cited as an important problem for micro enterprises and was ranked among the most important constraint particularly for smaller and younger firms. According to the authors, the most important limiting factors to access to finance were related primarily to interest rate, maturity of businesses, collateral requirements and lending procedures.

Ganbold (2008) find out that in Mongolia, access to finance especially external financing for Micro enterprises remain a major obstacle. According to his findings, he found that the large firms can easily access to finance their capital compared to micro enterprises. The main reasons that hindered them from access to finance were due to high interest rate, limited access to long term loan, collateral requirement and weak capacity to produce proper business planning.

Meanwhile, in the case of Thailand, Punyasvatsut (2011) found that 40 percent of Thai firms, mostly small can gain access to credit. The remaining was found difficulty in getting access into financing. Based on the feedback received from micro enterprises, inadequate collateral, lack of business experience, lack of sound business plans, non-performing loan history, and high transaction cost prevented them from accessing to finance.

Ung \& Hay (2011) studied the financial constraint faced by micro enterprises in Cambodia. Based on the findings by using 180 randomly selected firms, they found that the firms with high sales volume and high profit margin were easily get to access finance. Meanwhile, the small businesses were blocked from accessing into finance due to high collateral requirement, restrictions on the size of loans, high interest rates and short repayment periods. 
Tadesse (2011) investigated the failure of micro and small enterprises (MSEs) in the sub city of Addis Ababa Arada, Ethiopia. He used a survey covering 49 randomly selected MSEs to examine whether firms have problem of accessing to finance or not. Based on his findings, the lack of accessing to finance was caused by the factors such as inappropriate delivery of the loans, high collateral requirement, high interest rate, small size of loan and limited availability of financial instruments.

In Malaysia, the study conducted by Thaker (2015), Thaker et al. (2016), Aris (2006), and Meza (2012) revealed that an absence of adequate collateral and strict collateral requirement prevented micro enterprises to obtain loan from the financial institutions. In 2005, almost 56 percent of micro enterprises in Malaysia exposed to the difficulties to access external finance due to the lack of collateral (Aris, 2006).

\section{Technology Acceptance Model (TAM)}

The Technology Acceptance Model (TAM) is pioneered by Davis (1989) and received empirical support for being robust in predicting technology adoption in various contexts of technologies (McKinnon and Igonor, 2008; Park, 2009). TAM theorizes that an individual's behavioral intention to adopt a technological system or innovation is influenced by two beliefs, perceived usefulness and perceived ease of use. Use of the TAM is predicated on individuals having control over whether or not they use the system (Pearlson and Saunders, 2006). Perceived usefulness (PU) is defined as "the degree to which an individual believes that using a particular system would enhance his or her productivity" (Davis, 1989). Meanwhile, perceived ease of use (PEOU) is defined as "the degree an individual believes that using a particular system would be free of effort" (Davis, 1989).

The previous empirical studies have applied TAM in respective industries namely educational sector, SME's, general public and the manufacturing environment. For example, Ndubisi et al. (2001) tested the applicability of TAM for predicting entrepreneurs' technology usage and found it to be valid. Ramayah et al. (2002) also tested the applicability of TAM for Internet banking users and non-users. In the education sector Ramayah et al. (2003) tested the TAM incorporating motivational variables to explain Internet usage among students of institutions of higher learning. Ramayah and Aafaqi (2004) expanded the use of TAM in predicting e-library usage with the aid of self-efficacy. On the other hand, Ramayah et al. (2003) used the TAM to explain Internet shopping among the Malaysian public.

The technology acceptance model (TAM) is used in this study for its predictive ability in studies involving micro enterprises to engage in technology adoption. The causal relationships between perceived usefulness (PU), perceived ease of use (PEOU) and behavioural intention to use (BIU) Integrated Islamic Crowdfunding-Micro Enterprise (IICME) model are specified in the TAM to reflect the new environment of the proposed model (see Figure 1).

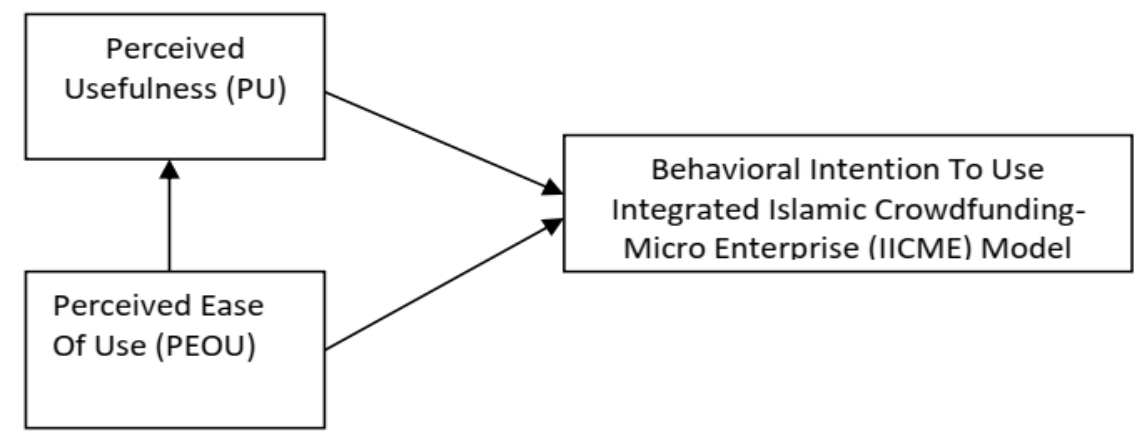

Figure 1: Technology Acceptance Model (TAM)

Based on TAM framework, the present study comes out with three main hypotheses, which are: 
(i) Hypothesis 1

Ho: There is no significant (positive) influence of perceived usefulness on the intention to engage in IICME model among micro enterprises.

Ha: There is a significant (positive) influence of perceived usefulness on the intention to engage in IICME model among micro enterprises.

(ii) Hypothesis 2

Ho: There is no significant (positive) influence of perceived ease of use on the intention to engage in IICME model among micro enterprises.

Ha: There is a significant (positive) influence of perceived ease of use on the intention to engage in IICME model among micro enterprises.

(iii) Hypothesis 3

Ho: There is no significant (positive) influence of perceived ease of use on perceived usefulness of IICME model among micro enterprises.

Ha: There is a significant (positive) influence of perceived ease of use on perceived usefulness of IICME model among micro enterprises.

\section{Crowdfunding}

Crowdfunding or crowd financing is "the collective effort of individuals who engage in network and pool their money, usually via the Internet, to support efforts initiated by other people or organizations" (Ordanini et al. 2011). Crowdfunding comes to practise with the help of web-based platform (i.e. RocketHub, Kickstarter, and IndieGoGo) and explosive growth of social media, with Facebook and Twitter at the forefront, as well as the affordable online payment transfer services such as Paypal and MoneyGram. The scope of crowdfunding projects is very diverse such as for business start-up, development projects, development and catastrophe aid, scientific research, entertainment such as video games, movies and music, political campaigns, utilities and many other targets.

Massolution (2013) defines four categories of crowdfunding platforms (CFPs) namely equity-based, lending-based, donation-based, and reward-based crowdfunding. In equitybased crowdfunding, funders receive compensation in the form of fundraiser's equity-based or revenue, or profit-share arrangements. Whereas in lending-based crowdfunding, funders receive fixed periodic income and expect repayment of the original principal investment. In donation-based crowdfunding, funders donate to causes that they want to support, with no expected compensation. Finally, in reward-based crowdfunding, the primary objective of funders is to gain a non-financial reward. Thus, equity-based and lending-based crowdfunding considered as crowdfunding for financial return, while donation-based and reward-based crowdfunding are used for campaigns that appeal to funders' personal beliefs and passions. However, the present research focuses on the donation-based and reward-based crowdfunding due to its popularity, flexibility and compatibility with the objective of micro enterprises in Indonesia.

In a few years crowdfunding has become a widespread and effective alternative for raising capital to support investment opportunity and source of venture capital. The crowdfunding market has grown tremendously in recent years. An industry report (Massolution, 2013 ) indicates that around $\$ 5.1$ billion total transactions occurred globally in 2013 (rising from $\$ 2.6$ billion in 2012), while a recent World Bank Report (2013) expects that the crowdfunding market to skyrocket and reach about $\$ 93$ billion in 2025 in developing countries alone. Such a growing market has garnered the attention of policy makers, which have legalized 
crowdfunding in many countries such as United States, United Kingdom, Finland, Australia, France, India, Brazil and Italy (World Bank, 2013; Massolution, 2013).

Since crowdfunding have been used widely in other countries to funds various philanthropic projects, entrepreneurial projects and charity purpose through small contribution from many sources, its application towards Micro enterprises' development may have significant contribution to socio-economic development, in particular. Hence, this study will therefore help in creating more awareness about crowdfunding among potential micro enterprises and crowd funders that are willing to involve with Integrated Islamic Crowdfunding-Micro Enterprise (IICME) model. This could therefore open an opportunity for another means of raising sustainable funds for micro enterprises.

\section{Developing Integrated Islamic Crowdfunding-Micro Enterprise (IICME) Model}

Our developed model which is known as Integrated Islamic Crowdfunding-Micro Enterprise (IICME) model involves two main different parties which are micro enterprises and crowd funders. Micro enterprises are consisting of existing or new enterprises. Meanwhile, crowd funders are consisting of the public or a large audience (the so-called "crowd"), where each individual provides a fund. Since the present study focuses on Islamic crowdfunding, the nature of crowdfunding will be based on Sadaqah-based crowdfunding (Donation-based crowdfunding), and Hibah-based crowdfunding (reward-based crowdfunding). The proposed model could be illustrated by Figure 2 .

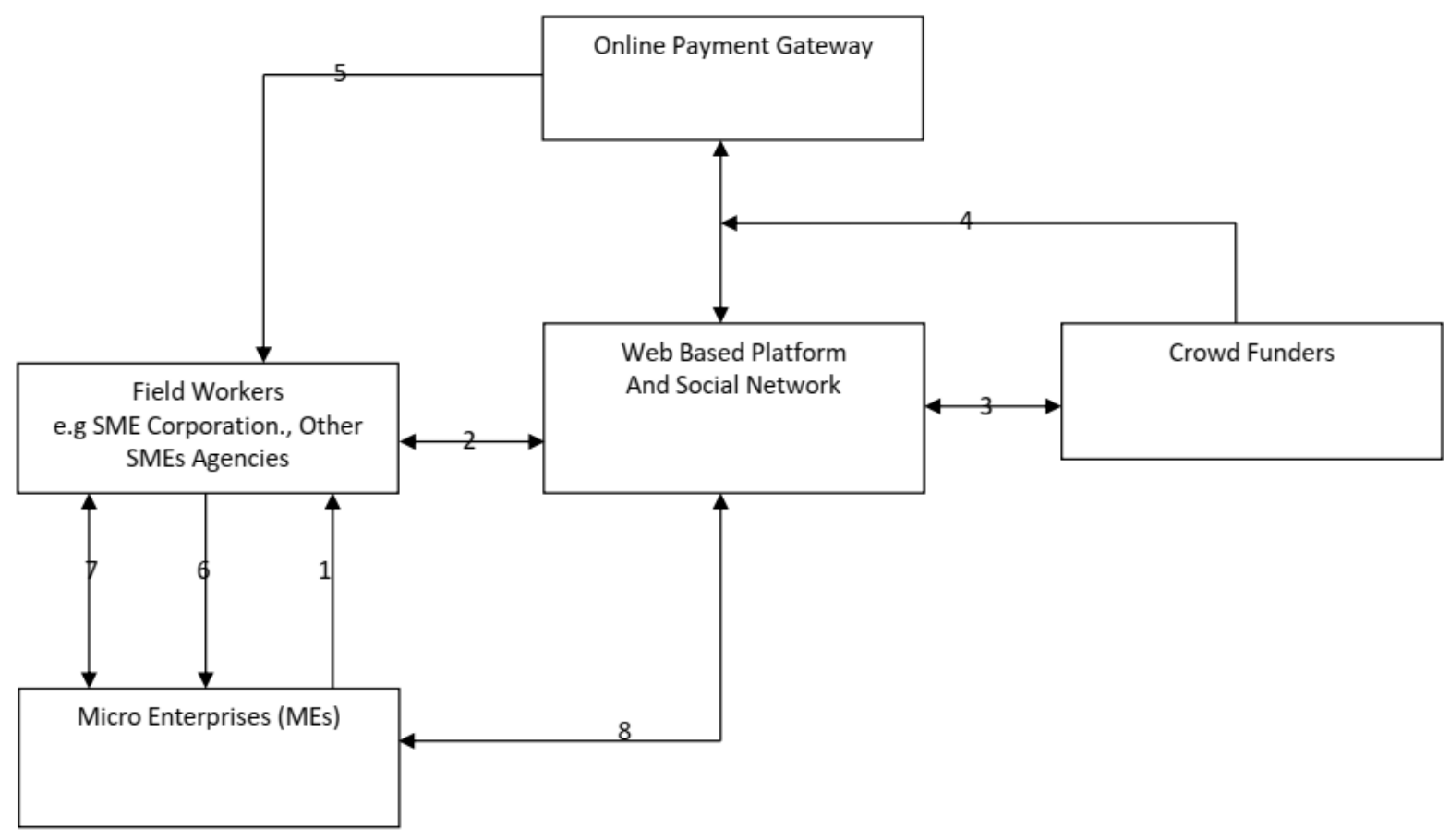

Figure 2: Integrated Islamic Crowdfunding-Micro Enterprise (IICME) Model

The following are the detailed explanation of Integrated Islamic Crowdfunding-Micro Enterprise (IICME) model:

1. Micro enterprises request for funding to field workers by submitting business proposal/projects. The field workers in Indonesia can be consisting of SMEs Corporation and other SMEs related agencies. These field workers know their potential micro enterprises and do all the screening process to get funding from crowd funders. 
2. Field workers submit micro enterprises proposals to the system or so called "Web Based Platform". Field workers can have their own "Web Based Platform" or outsourcing from third party. The field workers collect entrepreneur stories, business proposal, pictures, financing details, and uploads them to the system. The proposal/projects have to be funded within a predefined timeframe.

3. Crowd funders choose micro enterprises that they want to support based on their information uploaded into the system. Crowd funders browse the web to search financing requests and finally choose the micro enterprises that they are willing to help by providing capital or fund. Crowd funders can choose either to involve in Sadaqahbased crowdfunding (Donation-based crowdfunding), or Hibah-based crowdfunding (reward-based crowdfunding).

4. Crowd funders transfer/send funds through online payment gateways. Filed workers can have their own payment gateways through collaboration with existing financial institutions.

5. After receiving funding from crowd funders, the system will update the status of micro enterprises and keep track of received fund until it is ready to be distributed.

6. The system distributes the fund through field workers. Once the required fund is accumulated, the system will distribute the funds and notify corresponding field workers to get ready managing and supervising the micro enterprises. Field workers distribute the loans and update the status of loans through the system.

7. Field workers manage and monitor micro enterprises. Field workers must trace the progress and regularly updates the system with stories, pictures, or anything that shows the progress of micro enterprises. Field workers update micro enterprises' progress to the system. This will ensure transparency between the micro enterprises and the crowd funders.

8. The system communicates with micro enterprises for control and audit purposes through a simple communication media such as short message services (SMS)

\section{Research Methods}

\section{Data Collection, Sample, Data Analysis}

This study focuses micro enterprises in the area of East Java (Pasuruan, Malang, Kediri, Ponorogo, and Gresik). This area is chosen as the database for micro enterprises, recorded the highest number. A self-administered survey was used to collect the data. A purposive sampling was drawn for the survey. Sampling was conducted by distributing questionnaires to micro enterprises. A total of 250 questionnaires collected back from micro enterprises and only 177 questionnaires used further for data analysis.

The collected data was analyzed using SmartPLS version 3.2.7. The choice of SmartPLS was made on the basis of its ability to measure causal relationships among all latent construct simultaneously, while dealing with measurement errors in the structural model (Farooq, 2016; Hair et al., 2011). The advantages of PLS include minimal restrictions on measurement scales, sample size and residual distributions (Chin et al., 2003).

\section{Research Findings and Discussion}

\section{Descriptive Analysis- Demography Information}

As depicted in Table 1, 51.4 percent of the respondents are male while 48.6 percent are female. It is apparent that the dominance of male respondents explains the role of male in pursuing economic activity than females. It follows the traditional division of labor which is gender-based, with the wife responsible for the family and the husband being the breadwin- 
ner and head of household (Higgins et.al, 1994 \& Muhammad, 2012). This finding is relatively consistent with Indonesian's business environment where male business owners dominate compared to females even though the latter number is also increasing (Manan et.al, 2011).

Almost three-quarters (55.9 percent) of the respondents are between the age group of 20-40, few are over 40 years of age (44.1 percent). Consequently, the responses expressed in the survey well reflect the attitudes and perceptions of the middle-aged and younger respondents (that is if we consider those above 40 to be the older respondents). This also reflects that majority of the respondents fall within active working population (Abbasi et.al, 2012). This group of population is actively involved in operating businesses to search for an income and to uplift their standard of living. Almost 73 percent of the respondents are married. Thus, it seemed that the findings of the survey would be highly influenced by the married middle-aged respondents. The results also indicate that majority of the participants that engage with business are married and it shows that married participants are actively involved in doing business to fulfil the responsibility towards their family members.

Besides, in terms of educational level, majority of respondents are completed primary or secondary school (74.6 percent). A possible reason for them to start their own business at such a lower level of education is due to difficulties to find job with reasonable pay considering their present qualifications. On the other hand, 4 percent holding a college diploma or matriculation and about 19.7 percent holding at least a bachelor degree or above. This information reflects the tendency of an educated generation to be involved in businesses.

Table 1: Distribution of Respondents by Demography Information

\begin{tabular}{|c|c|c|}
\hline Items & Categories & Percent \\
\hline \multirow[b]{2}{*}{ Gender } & Male & 51.4 \\
\hline & Female & 48.6 \\
\hline \multirow{4}{*}{ Age } & $20-30$ & 27.7 \\
\hline & $31-40$ & 28.2 \\
\hline & $41-50$ & 28.2 \\
\hline & $>50$ & 15.8 \\
\hline \multirow{3}{*}{ Marital Status } & Single & 20.3 \\
\hline & Married & 72.9 \\
\hline & Divorced & 6.8 \\
\hline \multirow{7}{*}{ Education } & No Education & 1.7 \\
\hline & SD & 16.4 \\
\hline & SMP & 18.1 \\
\hline & SMA & 40.1 \\
\hline & Diploma & 4 \\
\hline & Degree & 16.9 \\
\hline & Postgraduate (Master/Phd) & 2.8 \\
\hline
\end{tabular}

\section{Descriptive Analysis- Business Information}

According to Kharusi (2003), the age of enterprises can be grouped into three categories where group " $0-5$ " years can be classed as young firms, while the bands " $6-10$ " and "11-15" years can be considered as middle aged, and "16 and over" as older firms. The results presented in Table 2 show that the majority of the respondents (58.2 percent) have been operating their business for $0-5$ years. Thus, from the findings of the current study, it is clear that 
most of micro enterprises are in their early stages of business, and can be classed as young firms. On the other hand, about 41.8 percent of the respondents had been in the middle and older stage of business.

In terms of sectors, majority of the respondents (83.6 percent) are engaged in the services sector followed by agricultural sector (13 percent) as shown in Table 2 . The remaining (3.4 percent) are in manufacturing sector. This finding is consistent with the overall profile of small and medium-sized businesses in Indonesia. The services sector accounted for the bulk of the total share of 95 percent in total SMEs. By component-based SMEs, micro enterprises constitute the largest proportion in the services sector with significant involvement in the area of businesses such as retail, restaurant, wholesale, transportation and communication, and professional services. In addition, the rapid growth of services sector in Indonesia is also influenced by the strong domestic demand and several government initiatives to boost services sector.

Furthermore, as depicted in Table 2, majority of respondents (94.3 percent) are in the Rp15.000.000, 00- Rp 55.000.000, 00 annual sales turnover group. The remaining 5.7 percent of the surveyed respondents fall in above Rp 56. 000.000,00 annual sales turnover group. The findings reflect the pattern of annual sales turnover of Indonesian micro enterprises which mainly consist of those with annual earnings between Rp15.000.000, 00- Rp 55.000.000, 00.

Regarding the number of employee, micro enterprises are having two groups as shown in Table 2. It is identified that 96.1 percent are having 1-5 employee and 3.9 percent are with more than 5 employee. Majority of the micro enterprises are having the number of employee less than five.

Table 2: Distribution of Respondents by Business Information

\begin{tabular}{|c|c|c|}
\hline Items & Categories & Percent \\
\hline \multirow{3}{*}{ No Of Years In Business } & $0-2$ Years & 33.3 \\
\hline & 3-5 Years & 24.9 \\
\hline & $>5$ Years & 41.8 \\
\hline \multirow{3}{*}{ Category Of Business } & Services & 83.6 \\
\hline & Agriculture & 13 \\
\hline & Manufacturing & 3.4 \\
\hline \multirow{6}{*}{ Annual Turnover } & less than Rp15.000.000,00 & 52 \\
\hline & Rp16.000.000,00- Rp25.000.000,00 & 23.7 \\
\hline & Rp26.000.000,00-Rp 35.000.000,00 & 7.3 \\
\hline & $\mathrm{Rp} 36.000 .000,00-\mathrm{Rp} 45.000 .000,00$ & 9 \\
\hline & Rp 46.000.000,00 - Rp 55.000.000,00 & 2.3 \\
\hline & above $\operatorname{Rp} 56.000 .000,00$ & 5.6 \\
\hline \multirow{3}{*}{ No of Employee } & $1-2$ & 84.2 \\
\hline & $3-5$ & 11.9 \\
\hline & More than 5 & 4 \\
\hline
\end{tabular}

\section{Descriptive Analysis- Financing Information}

Getting funds to start-up a business is a challenge to micro enterprises. Hence, for newer and micro scale business, there is difficulty for them to obtain external financing. Usually, most of the micro scale enterprises around the world use internally generated funds in 
the form of personal savings or the saving of their family to start their businesses (Beyene, 2002). The current finding is consistent with the previous studies conducted by Saleh et.al, (2008), Manan, et al (2010) and Aris, (2006). Most of the respondents used internally generated funding (personal \&family/relative/friend) to start their business ( 87 percent).

Furthermore, as depicted in Table 3 below, 16.9 percent of the respondents indicated that they applied external loan for last 6 month-1 year. Hence, it is appropriate to investigate the objectives for their application of the loan. Table 3 indicates the most commonly cited reason for applying for external finance: $7.3 \%$ of respondents stated it was for working capital, $5.6 \%$ of respondents said for capital purchases, and $1.1 \%$ of respondents said this was for expansion. Other reasons were that $0.6 \%$ of respondents said they needed finance for relocation.

Table 3: Distribution of Respondents by Financing Information

\begin{tabular}{|c|c|c|}
\hline Items & Categories & Percent \\
\hline \multirow{5}{*}{ Source of financing } & Personal & 78 \\
\hline & Friends/Family/Relative & 9 \\
\hline & Commercial Bank & 5.6 \\
\hline & Government Loan & 0.6 \\
\hline & Microfinance & 1.1 \\
\hline Applying Loan For last & Yes & 16.9 \\
\hline 6 month- 1 year & No & 83.1 \\
\hline Objective of Applying & Expansion & 1.1 \\
\hline \multirow{3}{*}{$\begin{array}{l}\text { Loan } \\
\text { (who applied loan for } 6 \text { month- } 1 \text { year) }\end{array}$} & Capital Purchase & 5.6 \\
\hline & Working Capital & 7.3 \\
\hline & Relocation & 0.6 \\
\hline
\end{tabular}

Although from the Table 3 shows that micro enterprises may eventually succeed in raising external finance (who applied external loan for last 6 month- 1 year), but they encountered problems in the process of obtaining loan. Hence, the respondents were asked about the difficulties in the process of applying and obtaining external finance for the last six month to one year.

As shown in Table 4 below, the respondents strongly stated that insufficient of amount of financing is the main difficulty in obtaining external finance; this received the highest percentage, $26 \%$. Respondents also agreed that long loan durations and characteristics of business were affecting them in obtaining external finance. These two factors received a percentage of 23.2 and $20.9 \%$, respectively. A further $19.2 \%$ also disclosed that they were faced the problems of strict collateral and documentation requirements. High interest rate also can be seen to place undue pressure on a micro enterprise to obtain finance (16.4\%).

Table 4: Type of Problem during Raising Loan

\begin{tabular}{|c|c|c|}
\hline Items & Categories & Percent \\
\hline \multirow{6}{*}{$\begin{array}{l}\text { Problems During Raising External } \\
\text { Finance } \\
\text { (who applied loan for } 6 \text { month- } 1 \\
\text { year) }\end{array}$} & Insufficient Of Amount Of Financing & 26 \\
\hline & Long Loan Durations & 23.2 \\
\hline & Characteristics Of Business & 20.9 \\
\hline & Strict Collateral Requirement & 19.2 \\
\hline & Strict Documentation Requirement & 19.2 \\
\hline & High Interest Rate & 16.4 \\
\hline
\end{tabular}


As indicated in Table 3 earlier, 83.1 percent of the respondents indicate that they did not apply for loan for last 6 month - 1 year. It is important to understand why micro enterprises do not apply for loan from any external financial institutions during this period. The questions that seek to explore the reasons for not applying external finance are included in the survey.

Table 5 shows the reasons for not obtaining financial assistance from external sources. Respondents are asked to select these factors on a dichotomous-scale ( $1=Y e s, 0=$ No). Majority of the respondents (53.1 percent) in this study consider themselves as not eligible to apply financial assistance from financial institutions because they are too young in the business operation. Micro enterprises may believe that it is difficult to get the trust of a bank if their businesses are still at infant age and unable to provide insufficient assets that can be used as collateral, no financial record and proper documentation to support the loan application.

Besides, 13 percent of the respondents also indicated that they did not apply for external finance due to high interest rate. Micro enterprises are not willing to or able to service expensive loans that carrying high rates of interest since high interest rate reflect high cost incurred. Unaware of the availability of loan facility also becomes a reason for not obtaining external finance, as indicated by 11.3 percent respondents. A possible explanation for this is that most micro enterprises do not apply the loan from financial institutions due to lack of knowledge or information of the existence of appropriate sources of finance.

Furthermore, imperfect information is found to be the main reason why enterprises failed to identify appropriate funding bodies (Harvey et al., 1992). There are nine percent of the respondents indicated that strict documentation requirement during the loan application has created difficulty for them to apply loan from the financial institutions. In addition, long duration of loan application is also one of the factors that affect the intention of micro enterprises to apply for loan from financial institutions. Almost 7.3 percent of the respondents of this study claimed that long duration of loan application has affected their intention to apply loan from external financial institutions at early period. For micro enterprises, the banks may take more time in processing their application. It is because the banks perceived micro enterprises as risky businesses and need thorough screening before the approval of their loan application. As a result of this, the financial institutions are unable to meet the need of micro enterprises that need immediate finance.

On the other hand, the findings also show that 5.6 percent of the respondent are not applied the loan because of lack of documentation or improper documentation to support their application for financing. Furthermore, 3.4 percent of the respondents point out that due to the absence of proper business plan, they are not able to apply external finance. Business plans are used by banks to evaluate the ability of business to repay loans and also give the owner-manager an opportunity to demonstrate his or her skills and experience (Read, 1998). Since there is an absence of proper business plan, it reduces the opportunity for micro enterprises to apply loan from financial institutions. This is due to lack of expertise of owner-managers of micro enterprises in the preparation of such plans.

In addition, since most of micro enterprises are small in size, they are unable to provide good collateral to compensate the total amount of loan from financial institutions. Thus, about 4 percent of the respondents in this study specified that they are reluctant to apply the loan due to inability to provide sufficient collateral. Apart from that, 3.4 percent of the respondents do not apply for loan from financial institutions because of poor credit history. Usually, the poor credit history may indicate inadequate repayment capacity which will limit their chance to obtain further financing from the financial institutions. This low scored reason 
indicates that most micro entrepreneurs in study are not having poor credit performance in the past or probably they are unwilling to declare or disclose their previous poor historical credit performance.

Table 5: Reasons for Not Applying Loan (who are not applied loan for 6 month- 1 year)

\begin{tabular}{|c|c|c|}
\hline Items & Categories & Percent \\
\hline \multirow{9}{*}{$\begin{array}{l}\text { Reasons for Not Applying Loan } \\
\text { (who are not applied loan for } 6 \text { month-1 year) }\end{array}$} & Too Young A Business & 53.1 \\
\hline & High Interest Rate & 13 \\
\hline & Unaware of Loan Facility & 11.3 \\
\hline & Strict Documentation & 9 \\
\hline & Long Duration of Loan Application & 7.3 \\
\hline & Insufficient Documents & 5.6 \\
\hline & No Proper Business Plan & 3.4 \\
\hline & Insufficient Collateral & 4 \\
\hline & Poor Credit History & 3.4 \\
\hline
\end{tabular}

\section{Assessment of Measurement Model}

The convergent validity was tested at the initial stage. During the test of convergent validity, indicator or items loadings, average variance extracted (AVE) and composite reliability (CR) were taken into the consideration. Based on the results presented in Table 3 , items' loading exceeded 0.6 for items, which meet the recommended value suggested by Hair et al. (2006).

In terms of AVE threshold or requirement, Hair et al. (2006) suggested that AVE should exceed 0.5. In the current study, AVEs were in the range of 0.817 and 0.865 . The CR value ranged from 0.969 to 0.982 , which meet the recommended value of 0.7 suggested by Hair et al. (2006). Table 6 shows the results of measurement model.

Table 6: Results of Measurement Model

\begin{tabular}{|c|c|c|c|c|}
\hline Construct & Items & Loadings & AVE & CR \\
\hline \multirow[t]{7}{*}{ Perceived Usefulness (PU) } & F1 & 0.927 & 0.817 & 0.969 \\
\hline & $\mathrm{F} 2$ & 0.915 & & \\
\hline & F3 & 0.894 & & \\
\hline & $\mathrm{F} 4$ & 0.903 & & \\
\hline & F5 & 0.917 & & \\
\hline & F6 & 0.842 & & \\
\hline & F7 & 0.925 & & \\
\hline \multirow[t]{10}{*}{ Perceived Ease of Use (PEOU) } & F8 & 0.88 & 0.846 & 0.982 \\
\hline & F9 & 0.911 & & \\
\hline & F10 & 0.932 & & \\
\hline & F11 & 0.947 & & \\
\hline & F12 & 0.935 & & \\
\hline & F13 & 0.937 & & \\
\hline & F14 & 0.925 & & \\
\hline & F15 & 0.926 & & \\
\hline & F16 & 0.88 & & \\
\hline & F17 & 0.924 & & \\
\hline
\end{tabular}




\begin{tabular}{|c|c|c|c|c|}
\hline Construct & Items & Loadings & AVE & CR \\
\hline \multirow[t]{8}{*}{ Behavioral Intention (F) } & F18 & 0.923 & 0.865 & 0.981 \\
\hline & F19 & 0.932 & & \\
\hline & $\mathrm{F} 20$ & 0.94 & & \\
\hline & $\mathrm{F} 21$ & 0.944 & & \\
\hline & $\mathrm{F} 22$ & 0.939 & & \\
\hline & $\mathrm{F} 23$ & 0.925 & & \\
\hline & $\mathrm{F} 24$ & 0.905 & & \\
\hline & F25 & 0.931 & & \\
\hline
\end{tabular}

After conducting earlier test of convergent validity, next, the discriminant validity needs to be tested. Previously, Fornell-Larcker (1981) criterion has been used to test discriminant validity. However, there has been a criticism on Fornell-Larcker (1981) criterion where, it is not reliably detecting the lack of discriminant validity in common research situations (Henseler et al., 2015).

Thus, Henseler et al., (2015) have suggested an alternative approach to access discriminant validity using heterotrait-monotrait ratio of correlations. Henseler et al. (2015) also went on to demonstrate the superior performance of this method by means of a Monte Carlo simulation study. As such we have also tested the discriminant validity using this new suggested method and the results are shown in Table 7. If the HTMT value is greater than $\mathrm{HTMT}_{0.85}$ value of 0.85 (Kline, 2011), or HTMT ${ }_{0.90}$ value of 0.90 (Gold et al., 2001) then there is a problem of discriminant validity.

Although the current results showed that all the values above the HTMT ${ }_{0.90}$ (Gold et al., 2001) and also the $\mathrm{HTMT}_{0.85}$ (Kline, 2011) as shown in Table 7, the results were indicated that discriminant validity has been ascertained by using HTMT inference. HTMT inference is using bootstrapping technique suggested by Henseler et al. (2015). Using this approach, if the confidence interval does not show a value of 1 on any of the constructs, it confirms discriminant validity. Based on these results, it indicates that measurement model has adequate convergent validity and discriminant validity.

\section{Table 7: HTMT Criterion}

\begin{tabular}{cccc}
\hline & BI & PEOU & PU \\
\hline BI & & & \\
\hline PEOU & 0.921 & & \\
& $\mathrm{Cl} .90(0.887,0.944)$ & & \\
\hline PU & 0.89 & 0.933 \\
& $\mathrm{Cl} .90(0.798,0.941)$ & $\mathrm{Cl} .90(0.862,0.966)$ & \\
\hline
\end{tabular}

\section{Assessment of Structural Model}

Ramayah et al. (2016) have suggested using $R^{2}$ to observe the goodness of the structural model. According to Hair et al. (2011), coefficient of determination and the level of significance of the path coefficients (beta values) can be captured by $R^{2}$. The $R^{2}$ for the current research is 0.83 , suggesting that 83 percent of the variance of behavioral intention of using IICME model can be explained by perceived ease of use and perceived usefulness.

Subsequently, in order to assess the statistical significance of path coefficients, the current study has calculated the path coefficients of the structural model and performed 
bootstrap analysis (re-sampling $=500$ ) (please see Table 8). Based on results, it revealed that perceived usefulness and perceived easy to use has a positive relationship with behavioral intention to use IICME model with $b=0.26, p<0.10$ and $b=0.667, p<0.01$, respectively. In addition, perceived easy to use has a positive relationship and direct effect with perceived usefulness with $b=0.91$ and significant at $p<0.05$. Thus, $\mathrm{H} 1, \mathrm{H} 2$, and $\mathrm{H} 3$ are supported. Table 8 shows the results of Structural Model.

Table 8: The Results of Structural Model

\begin{tabular}{cccccc}
\hline Hypothesis & R/ship & Std. Beta & Std. error & t-value & Decision \\
\hline H1 & PEOU-> BI & 0.667 & 0.161 & 4.14 & Supported \\
\hline H2 & PU -> BI & 0.26 & 0.165 & $1.60^{*}$ & Supported \\
\hline H3 & PEOU -> PU & 0.907 & 0.028 & 32.82 & Supported \\
\hline
\end{tabular}

*significance at $10 \%$, one-tailed test

\section{Importance-Performance Map Analysis (IPMA)}

Ringle and Sarstedt (2016) stated that the IPMA's goal is to identify predecessors which have a relatively low performance but high importance for the target constructs. IPMA becomes a very useful analytical tool in PLS-SEM. IPMA graphically extends the standard path coefficient estimates in more practical way (Ringle and Sarstedt, 2016).

In this study, the behavioral intention of adopting ICSMEs is a target construct, which is predicted by two predecessors (perceived ease of use and perceived usefulness); refer to Figure 3. This study has performed IPMA and results is presented in Figure 3 and Table 8 . The IPMA reveals that the construct PEOU has high performance and also an important variable in the prediction of behavioral intention of adopting ICSMEs. Meanwhile, PU already has high in performance but low importance compared than PEOU.

\section{Figure 3: Importance-Performance Map}

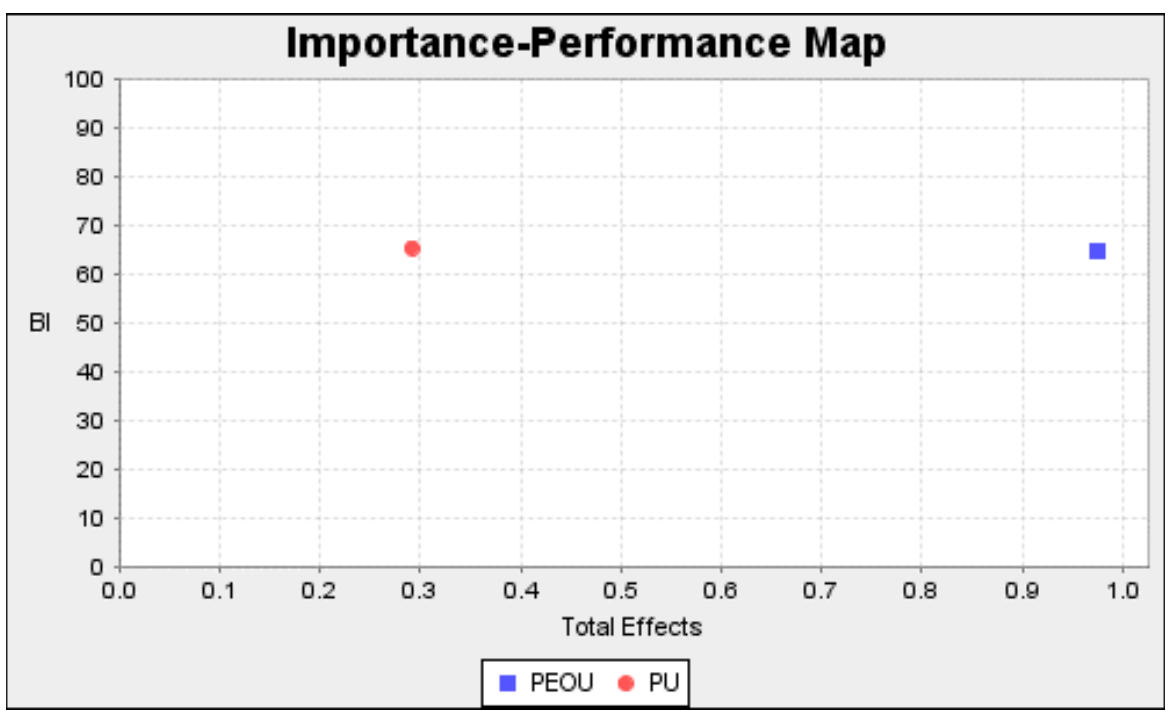

Table 8: Importance-Performance Map Analysis Statistics

\begin{tabular}{ccc}
\hline Construct & Importance (Total Effect) & Performance (Index Values) \\
\hline PEOU & 0.98 & 64.5 \\
\hline PU & 0.30 & 64.4 \\
\hline
\end{tabular}




\section{Discussion}

In this study, the behavioral intention of micro enterprises to use Integrated Islamic Crowdfunding-Micro Enterprise (IICME) model was found to depend on perceived usefulness and perceived easy to use. Perceived usefulness is the perception that a given a technological-based system (online fund raising), it will help a user (in our case micro enterprises) to achieve his or her work goals. Micro enterprises need a mechanism that could help them to raise financing to support and expand their businesses. Thus, by using IICME model which is through online platform, it will help micro enterprises to raise fund for start-up or expanding their business in the context of East Java, Indonesia. The findings also suggest that micro enterprises would like to engage with the proposed model because they believed that IICME model going to bring benefit and useful for them. This perception motivated them to utilise the technology for their work. Indeed, since IICME model is involving platform to raise capital, thus micro enterprises might only involve with this model if they believe that it provides useful and interactive platform. This finding is consistent with Venkatesh et al. (2000), Abassi et al. (2011), and Cheng et al. (2006). This model is expected to create a positive perception towards micro enterprises, who are looking for alternative external source of funding in Indonesia.

On the other hand, according to Davis (1989), the degree to which a person believes that easy-to-use technology was associated with greater intent to use it is known as perceived ease of use. Thus, the easier to involve with IICME model, it will attract micro enterprises to raise fund using this platform. It means micro enterprises will have a positive attitude toward the use of IICME model when they feel greater benefits and easy accessibility into various elements such as faster information search, risk availability, projects, rewards offered and security. This finding is also similar to Davis (1989), Gefen et al. (2004) and Yi et al. (2003). Meanwhile, perceived ease of use was positively associated with perceived usefulness. It means that the easier the system was to use, the more useful it was perceived to be. Thus, IICME model may need to have the features that useful to the user particularly micro enterprises, who are looking for external fund.

\section{Conclusion}

Although the statistics show a very significant share of firms in Indonesia are microenterprises, a limited accessibility for external fund among this segment results in the limiting of opportunities for growth and restricting a potential increase in financial inclusion for them. The lack of collateral, insufficient legal status, high transaction costs, insufficient information and documentation, lack of financial track record, nature and quality of business, rigidity of the financing procedure and lack of awareness on financial facility are among the prominent factors that hindered micro enterprises from accessing external finance and, as a result, they are unable to grow their businesses.

This paper has developed Integrated Islamic Crowdfunding Micro Enterprise (IICME) model. The model is expected to assist micro enterprises to meet their financing need for business expansion or start-up in East Java, Indonesia. Later, this study has empirically tested the behavioral intention of micro enterprises in adopting this model by applying TAM. The author has extended the application of TAM in the context of Islamic crowdfunding and micro enterprises. This study has proven that both perceived usefulness and perceived ease of use are directly significant in influencing the micro enterprises' intention to use IICME model. The findings of this study can be used to develop a specific framework in which to examine other components of using IICME's behavior and to plan appropriate intervention strategies to increase its capacity in boosting micro enterprises' development in Indonesia. 


\section{References}

Abdullah, M.A. (1999). Small and Medium Enterprises in Malaysia: Policy Issues and Challenges. Ashgate, England

Abbasi, M.S., Chandio, F.H., Soomro, A.F., \& Shah, F. (2011). Social influence, voluntariness, experience and the internet acceptance: An extension of technology acceptance model within a south-Asian country context. Journal of Enterprise Information Management, Vol. 24(1):30-52.

Aris N.M (2006). SMEs: Building Blocks for Economic Growth. Paper Presented at National Statistics Conference, Department of Statistics, Malaysia 4-5 September

Badan Pusat Statistik. (2014). Survey Industri Mikro dan Kecil 2014. Jakarta.

Beyene, A. (2002). Enhancing the Competitiveness and Productivity of Small and Medium Scale Enterprises (SMEs) in Africa: An Analysis of Differential Roles of National Governments through Improved Support Services. Africa Development, Vol. 27(3) : pp. 130-156.

Berger, A. N., \& Udell, G. F. (2006). A more complete conceptual framework for SME finance. Journal of Banking \& Finance, 30(11), 2945-2966.

Burger, N., C. Chazali, A. Gaduh, A.D. Rothenberg, I. Tjandraningsih and S. Weilant. (2015). Reforming Policies for Small and Medium Enterprises in Indonesia, Jakarta, Indonesia, RAND Corporation in collaboration with Tim Nasional Percepatan Penanggulangan Kemiskinan (TNP2K), Jakarta, Indonesia.

Cheng, T., Lam, D.Y.C. \& Yeung, A.C.L. (2006). Adoption of internet banking: an empirical study in Hong Kong. Decision Support Systems. 42, (3), pp. 1558-1572.

Chin, W. W., B. L. Marcolin, and P. R. Newsted (2003). A Partial Least Squares Latent Variable Modeling Approach for Measuring Interaction Effects: Results from a Monte Carlo Simulation Study and an Electronic-Mail Emotion / Adoption Study. Information Systems Research (14)2, pp. 189-217

Davis, F. D. (1989). Perceived usefulness, perceived ease of use, and user acceptance of information technology. MIS Quarterly, 13, 983-1003.

Farooq, M. S., \& Radovic-Markovic, M. (2016, October). Modeling entrepreneurial education and entrepreneurial skills as antecedents of intention towards entrepreneurial behaviour in single mothers: a PLS-SEM approach. In Entrepreneurship: Types, Current Trends and Future Perspectives, Presented at the Fifth International Conference "Employment, Education and Entrepreneurship"(EEE 2016), Faculty of Business Economics and Entrepreneurship, University of Belgrade, Belgrade (pp. 198-216).

Fornell, C., \& Larcker, D. F. (1981). Structural equation models with unobservable variables and measurement error: Algebra and statistics. Journal of marketing research, 382-388.

Ganbold, B. (2008). Improving Access to Finance: International Good Experiences and Lessons for Mongolia. Institute of Development Economics, Tokyo.

Gefen, D. and Straub, D.W. (2004). Consumer trust in B2C e-commerce and the importance of social presence: experiments in e-products and e-services. Omega, Vol. 32, pp. 407-24.

Gold, A.H., Malhotra, A., \& Segars, A.H. (2001). Knowledge management: an organizational 
capabilities perspective. Journal of Management Information Systems 18(1): 185-214

Hair, J., Hollingsworth, C. L., Randolph, A. B., \& Chong, A. Y. L. (2017). An updated and expanded assessment of PLS-SEM in information systems research. Industrial Management \& Data Systems, 117(3), 442-458.

Hair, J.F., Ringle, C.M., Sarstedt, M., (2011). PLS-SEM: indeed a silver bullet. J. Marketing Theory Pract. 19 (2), 139-152.

Hair et al., (2006). Multivariate Data Analysis (6th ed.). Prentice Hall, Upper Saddle River

Harvey, J., Lefebvre, L.A. and Lefebvre, E. (1992). Exploring the relationship between productivity problems and technology adoption in small manufacturing firms,. IEEE Transactions On Engineering Management, 39(4): 352-58.

Henseler, J., Ringle, C. M., \& Sarstedt, M. (2015). A new criterion for assessing discriminant validity in variance-based structural equation modeling. Journal of the academy of marketing science, 43(1), 115-135.

Henseler, J., Ringle, C. M., \& Sarstedt, M. (2016). Testing measurement invariance of composites using partial least squares. International Marketing Review, 33(3), 405-431.

Higgins C. et.al (1994). Impact Of Life-Cycle Stage And Gender On The Ability To Balance Work And Family Responsibility. Family Relation, Vol. 43 (2), pp. 144-155

Irjayanti, M., \& Azis, A. M. (2012). Barrier factors and potential solutions for Indonesian SMEs. Procedia Economics and Finance, 4, 3-12.

Kharusi A.A. (2003). Financing Small Business In Oman. Unpublished PhD Thesis, Loughborough University

Kline, R.B. (2011) Principles and practice of structural equation modeling. New York, Guilford Press

Machmud, Z., \& Huda, A. (2010). SMEs' access to finance: an Indonesia case study. Selected East Asian Economies', in Harvie, C., S. Oum, and D. Narjoko (eds.), Small and Medium Enterprises (SMEs) Access to Finance in Selected East Asian Economies. ERIA Research Project Report, 14, 261-290.

Manan, A. B., Othman, S.K., \& Shahadan, A. (2011, June). Descriptive analysis on the pattern of SME financing in Malaysia. In 2011 3rd International Symposium \& Exhibition in Sustainable Energy \& Environment (ISESEE) (pp. 139-147). IEEE.

Massolution (2013). 2013CF- Crowdfunding Industry Report.

Meza V.S. (2012). Microfinancing Access Constraints In Both Malaysia And Costa Rica: Case Of The Microenteprises Sector. Paper Presented At International Conference On Social Sciences \& Humanities 2012, Kuala Lumpur Malaysia.

Muhammad (2012). Challenges of Micro Finance and Prospect of Introducing and Developing IMIM in Nigeria. Unpublished PhD Thesis, International Islamic University Malaysia (IIUM)

McKinnon, K., \& Igonor, A. (2008, November). Explaining eLearning perceptions using the technology acceptance model and the theory of planned behavior. In E-Learn: World Conference on E-Learning in Corporate, Government, Healthcare, and Higher Education (pp. 
2994-2999). Association for the Advancement of Computing in Education (AACE).

Park, S. Y. (2009). An Analysis of The Technology Acceptance Model in Understanding University Students' Behavioral Intention to USe E-Learning. Journal of Educational Technology \& Society, 12(3), 150.

Punyasvatsut C. (2011). SMEs Access to Finance in Thailand. In Harvie C. et.al (2010). Small And Medium Enterprises (SMES) Access To Finance In Selected East Asian Economies. ERIA Research Project Report 2010, No. 14

Read, L. (1998). The Financing of Small Business: A Comparative Study of Male and Female Business Owners (Routledge, London)

Saleh, A.S., Caputi P., \& Harvey C. (2008). Perceptions of Business Challenges Facing Malaysian SMES: Some Preliminary Results. Paper Presented At 5th SMEs in a Global Economy Conference, August 2nd-3rd, Senshu University, Kandajimbocho, Tokyo, Japan

Stephanou C, Rodriguez C (2008) Bank Financing To Small- And Medium-Sized Enterprises (SMEs) In Colombia. World Bank Policy Research Working Paper 4481

Tadesse, B. (2011). Finance as success or failure factor for micro and small enterprises in Addis Ababa: the case of Arada sub-city. Addis Ababa University.

Tambunan, T. T. (2011). Crisis-Adjustment Strategies Adopted by SMEs in Coping with the 2008-2009 Global Economic Crisis: The Case of Indonesia. Asian Journal of Agriculture and Development, 8(1362-2016-107704), 57-77.

Thaker M.A.M.T (2015). The Problems Faced By Malaysian Micro Enterprises In Accessing External Finance: An Empirical Study. Paper Presented At International Symposium on Business and Management - Fall Session 2015, 8 September-10 September 2015. Kyoto, Japan

Thaker M.A.M.T, Mustafa Omar Mohammed, Jarita Duasa \& Moha Asri Abdullah (2016). Measuring The Factors That Determine Micro Enterprises' Intention To Use Integrated Cash Waqf Micro Enterprise Investment (ICWME-I) Model As A Source Of Financing. Gadjah Mada International Journal of Business, Vol. 18, No.2

Ndubisi, N. O., Jantan, M., \& Richardson, S. (2001). Is the technology acceptance model valid for entrepreneurs? Model testing and examining usage determinants. Asian Academy of Management Journal, 6(2), 31-54.

Ordanini, A., Miceli, L., Pizzetti, M., \& Parasuraman, A. (2011). Crowd-funding: transforming customers into investors through innovative service platforms. Journal Of Service Management, 22(4), 443-470.

Pearlson, K. E., \& Saunders, C. S. (2006). Managing \& using information systems: A strategic approach. John Wiley \& Sons.

Razak, D. A., \& Maulana, H. Measuring Barriers To Access Financial Servicesin East Java, Indonesia: A Confirmatory Factor Analysis (CFA). International Journal of Business, Economics and Law, Vol. 12, Issue 3 (April)

Ramayah, T., Ma'ruf, J. J., Jantan, M., \& Osman, M. (2002). Technology Acceptance Model: is it applicable to users and non-users of internet banking. In The proceedings of the international Seminar, Indonesia-Malaysia, the role of harmonization of Economics and 
business discipline in global competitiveness, Banda Aceh, Indonesia (pp. 14-15).

Ramayah, T., Jantan, M., Mohd Noor, M. N., Razak, R. C., \& Koay, P. L. (2003). Receptiveness of internet banking by Malaysian consumers: The case of Penang. Asian Academy of Management Journal, 8(2), 1-29.

Ramayah, T., \& Aafaqi, B. (2004). Role of self-efficacy in e-library usage among students of a public university in Malaysia. Malaysian Journal of Library \& Information Science, 9(1), 39-57.

Ramayah, T., Ling, N. S., Taghizadeh, S. K., \& Rahman, S. A. (2016). Factors influencing SMEs website continuance intention in Malaysia. Telematics and Informatics, 33(1), 150-164.

Ringle, C. M., \& Sarstedt, M. (2016). Gain more insight from your PLS-SEM results: The importance-performance map analysis. Industrial management \& data systems.

Tambunan, T.T.H., (2009). SME in Asian Developing Countries. London: Palgrave Macmillan Publisher. Tambunan, T.T.H., 2008, Development of SMEs in ASEAN, Readworthy Publications, Ltd, New Delhi.

Ung L. \& Hay S. (2011). SMEs Access to Finance in Cambodia. In Harvie C. et.al (2010). Small And Medium Enterprises (SMES) Access To Finance In Selected East Asian Economies. ERIA Research Project Report 2010, No. 14

Venkatesh, V., Davis, F.D., (2000). A theoretical extension of the technology acceptance model: four longitudinal field studies. Manage. Sci. 46 (2), 186-204.

World Bank (2013). Crowd funding's potential for the developing world. Washington, DC: World Bank.

Yi, M.Y. \& Hwang, Y. (2003). Predicting the use of web-based information systems: self-efficacy, enjoyment, learning goal orientation, and the technology acceptance model. International Journal of Human-Computer Studies, vol. 59, no. 4, pp. 431-449. 